\title{
Young women selling sex online - narratives on regulating feelings
}

This article was published in the following Dove Press journal:

Adolescent Health, Medicine and Therapeutics

16 February 2015

Number of times this article has been viewed

\section{Linda S Jonsson' \\ Carl Göran Svedin' \\ Margareta Hydén ${ }^{2}$}

'Division of Child and Adolescent Psychiatry, Department of Clinical and Experimental Medicine, Faculty of Health Sciences, Linköping University, Linköping, Sweden; ${ }^{2}$ Department of Social and Welfare Studies, Linköping University, Norrköping, Sweden
Correspondence: Linda S Jonsson Department of Child and Adolescent Psyciatry and Department of Clinical and Experimental Medicine, Faculty of Health Sciences, Linköping University, SE-58I 85 Linköping, Sweden Email linda.s.jonsson@liu.se
Abstract: The current study concerns young women's life stories of their experiences selling sex online before the age of 18 . The aim was to gain an understanding of young women's perceptions of the reasons they started, continued, and stopped selling sex. The study included interviews with 15 young women between the ages of 15 and $25(\mathrm{M}=18.9)$. Thematic analysis was used to identify similarities and differences in the narratives. Three themes and eight subthemes were identified in relation to different stages in their lives in the sex trade. The themes were organized into three parts, each with its own storyline: "Entering - adverse life experiences"; traumatic events: feeling different and being excluded. "Immersion - using the body as a tool for regulating feelings"; being seen: being touched: being in control: affect regulation and self-harming. "Exiting - change or die"; living close to death: the process of quitting. The informants all had stable social lives in the sense that they had roofs over their heads, food to eat, and no substance-abuse issues. None had a third party who arranged the sexual contacts and none were currently trafficked. They described how their experiences of traumatic events and of feeling different and excluded had led them into the sex trade. Selling sex functioned as a way to be seen, to handle traumatic events, and to regulate feelings. Professionals working with young people who sell sex online need to understand the complex web of mixed feelings and emotional needs that can play a role in selling sex. Young people selling sex might need guidance in relationship building as well as help processing traumatic experiences and ending self-harming behavior. Further studies are needed on the functions of online sex selling and on the exit process for young people, in order to prevent entrance and facilitate exiting.

Keywords: adolescent, women, affect regulation, selling sex, prostitution, online

\section{Introduction}

This study focuses on the life stories of young people 15-25 years of age who have been involved in online prostitution or, as termed in this paper, selling sex. Worldwide, most research on this topic has focused on adults, even though studies from Nordic countries and Canada show that the mean age individuals start selling sex is around $15 .^{1-3}$ In this study, we interviewed young women about their experiences selling sex online as children, before the age of 18 .

\section{Selling sex, a form of sexual exploitation}

Sexual exploitation of children under the age of 18 includes trafficking, prostitution, and child pornography. ${ }^{4}$ In most jurisdictions and social settings, sexual exploitation of children is seen as serious and harmful to the children involved. Under international law and in certain branches of feminist research, selling sex is seen as harmful to the seller and equivalent to sexual abuse. ${ }^{5,6}$ Under Swedish law, it is a crime to purchase sexual 
services from an individual of any age, but if the person is a child under the age of 15 , it is considered rape. This means that a child in the sex trade is always the victim of a crime, even if it was the child who initiated the contact with the buyer. ${ }^{7}$

\section{Psychosocial background}

Most of the research on this subject, both qualitative and quantitative, suggests that young people involved in the sex trade come from disadvantaged backgrounds and are a vulnerable group. Svedin and Priebe found that the mental health of Swedish young people (average age, 18.2) who sold sex was worse, especially among girls, than that of the reference group. ${ }^{2}$ Furthermore, studies show that young people involved in selling sex have more problematic relationships with their parents, ${ }^{8-12}$ less often live with both parents, ${ }^{9}$ and more often live in abusive families. ${ }^{13,14}$ In addition, correlations have been found between selling sex and sexual abuse. ${ }^{2,3,13,14}$ In a study by Svensson et al, as many as 78.4\% of young people who had sold sex had been exposed to sexual abuse, and $51 \%$ had been exposed to penetrating abuse. ${ }^{15}$ In a longitudinal study by Kaestle, child sexual abuse and running away from home was critical risk factors for adolescents who had sold sex. ${ }^{16}$ In a study by Roe-Sepowitz, emotional abuse was found to increase girls' vulnerability to prostitution and also appeared more important than experiences of childhood physical or sexual abuse. ${ }^{12}$

\section{Entering and staying in the sex trade}

Previous research suggests that challenging background factors and difficult current life situations may explain why individuals engage in risky behavior, including entering into and staying in the sex trade. Young people's challenging backgrounds may lead them into risky behavior such as running away from home, ${ }^{12,16-19}$ drug abuse, ${ }^{20,21}$ earlier alcohol debut, ${ }^{2}$ antisocial behavior, ${ }^{2}$ and self-harming behaviors. ${ }^{15}$ Qualitative studies also indicate that some of these young people may engage in risky online sexual behavior. ${ }^{22,23}$ As stated, young people may enter the sex trade because of challenging life situations. For example, they may be in need of money, drugs, or a place to stay. In a national survey from the US, children who do not live at home have been identified as the largest risk group for sexual exploitation. ${ }^{24}$ Studies have also shown that for some a third party, such as a pimp, a boyfriend, or another adult introduces them to the sex trade and maintains their contacts with the buyers. ${ }^{24-26}$ In some cases, young people are sold and transported between or within countries, often referred to as "trafficking for sexual purposes". ${ }^{27}$ While practical needs or coercive situations may lead to sex selling, studies indicate that there are other factors that are important for young people who enter and stay in the sex trade. For example, some are motivated by curiosity and excitement. ${ }^{28}$

\section{Exiting the sex trade}

Few studies discuss how children extricate themselves from the sex trade, though there are theoretical models discussing the different stages adult women go through in the process of exiting street-based prostitution. ${ }^{29,30}$ Baker et al developed an integrated six-stage model describing this process: immersion, awareness, deliberate planning, initial exit, final exit and, in some cases, re-entry. ${ }^{30}$ It has not yet been examined whether these models and stages would be applicable to children selling sex online.

\section{Shifting arena for selling sex}

In many areas of the world, such as North America and Sweden, the marketplace for sex has gradually shifted from being street-based to being online-based. .,31 $^{\text {This trend }}$ includes an increase in online-related sex selling among young people. In a study by Fredlund et al, 1.5\% of Swedish youth (average age 18.3) had experienced selling sex, and a majority of the connections between buyer and seller were made online. ${ }^{9}$ Cunningham and Kendall argue that the Internet may attract new groups of sex sellers among adults. ${ }^{31}$ Swedish studies of adolescents suggest that the total number of youth selling sex has not increased, but the Internet has become the most common way to establish contacts for sex selling. ${ }^{2,9}$ The accessibility and rapid speed of communication offered by the Internet may facilitate introduction to the sex trade for young people. These factors may also make it easy for youth to stay in the sex trade. The Internet environment also fosters a situation in which people find it difficult to set boundaries. $^{22}$ In the model by Cooper, easy access, affordability, and anonymity are some of the reasons the Internet is so popular for facilitating sexual activity. ${ }^{32}$ The Internet has also made it easier for adults to connect with children in order to approach them sexually. In such instances, the children might be at a disadvantage due to a power imbalance, ${ }^{33}$ particularly with regard to negotiating online about selling sex. ${ }^{22}$

\section{The current study}

Although many studies have described the backgrounds of young people in the sex trade, few have focused on how they themselves perceive their motivations for selling sex. By listening to the stories of young women about their experiences with selling sex online before the age of 18 , and exploring how these 
stories give meaning and coherence to their life situations, we aimed to study the informants' perceptions of their motivations for entering, staying in, and exiting the sex trade.

In this paper, the phrases "selling sex" and "sex trade" were used, referring to the experience of receiving compensation (eg, money, alcohol, drugs, model contracts) for sex acts. By the term "selling sex online" we meant both sexual services sold online and sex selling offline in which the connection between buyer and seller was made via the Internet or a mobile phone. A "child" was defined as any human being under the age of 18 , according to the United Nations Convention on the Rights of the Child. ${ }^{34}$ People between 15 and 18 years old were referred to as "young people" or "young persons".

\section{Method}

\section{Informants}

The current study concerns the stories of 15 young women who described their lives selling sex online as children. Young people who met the criteria for inclusion in this study were between 15 and 25 years old at the time of the interview, had sold sex before the age of 18 , and had used the Internet for making contact with their buyers $(M=18.9)$. Purposive sampling was used and the informants were recruited through various channels (Table 1). The study was intended to include young men as well as young women, but none of the contacts made with men resulted in face-to-face interviews.

The 15 informants in the study lived in different parts of Sweden and came from major cities as well as rural areas. Some still attended school, while others were working or were on maternity or sick leave. All described having poor psychological health currently and/or previously. Ten of the 15 young women said that they were taking prescription medications, some suffered from depression or insomnia, and all had had suicidal thoughts. The mean age on the first occasion of selling sex was 14.1 years, and all informants had sold sex more than once. All used the Internet as the channel through which they contacted their buyers, which was the focus of a previously published article. ${ }^{22}$

\section{The interviews}

The interview method was inspired by the teller-focused interview (TFI), ${ }^{35}$ an interview model developed specifically for studies of sensitive topics such as interpersonal violence and/or studies of vulnerable informants. The TFI is oriented towards narration. In order to support and facilitate narratives, the practice of teller-focused interviewing is based on a dialectical way of thinking about the relationship between the interviewer and the informant. The interview situation is seen as a co-construction where the accounts are developed together. The TFI model includes a series of strategies for supporting the teller and dealing with the power imbalance between the interviewer and the informant. For example it is crucial to establish a relationally safe space, meaning that the informant feels in control and the researcher needs to take on the role of responsibility. Being responsible meaning for example, to interact and stop, if the situations seem to become too emotionally painful or chaotic. $^{35}$

All of the informants were interviewed on at least one occasion. A time limit of 2 hours was set and if an informant

Table I Participant information

\begin{tabular}{|c|c|c|c|c|c|}
\hline Participant & $\begin{array}{l}\text { Age at time } \\
\text { of interview }\end{array}$ & $\begin{array}{l}\text { Interview contact } \\
\text { channel }\end{array}$ & $\begin{array}{l}\text { Age at first occasion } \\
\text { of selling sex }\end{array}$ & $\begin{array}{l}\text { Number of sex- } \\
\text { selling occasions }\end{array}$ & $\begin{array}{l}\text { Time since last sex- } \\
\text { selling occasion }\end{array}$ \\
\hline Anna & 24 & Journalist & 14 & $>50$ & 8 years \\
\hline Bonnie & 16 & Journalist & 14 & $>50$ & I year \\
\hline Claudia & 24 & Journalist & 13 & $>50$ & I month \\
\hline Holly & 22 & NGO & 14 & $>50$ & I week \\
\hline Ella & 19 & Residential treatment clinic & 15 & $20-30$ & 6 months \\
\hline Nikki & 21 & Journalist & 15 & $20-30$ & 6 months \\
\hline Tracy & 20 & NGO & 14 & $>50$ & 2 months \\
\hline Diana & 21 & Journalist & 13 & $<20$ & 4 years \\
\hline Johanna & 17 & Web page & 15 & $30-50$ & I month \\
\hline Linda & 16 & Participant herself & 13 & $30-50$ & 3 months \\
\hline Erica & 18 & NGO & 13 & $>50$ & 2 years \\
\hline Selma & 16 & Web page & 15 & $10-20$ & 2 months \\
\hline Stella & 17 & Residential treatment clinic & 13 & $>50$ & I year \\
\hline Mandy & 16 & Participant herself & 15 & $10-20$ & 6 months \\
\hline Natalie & 17 & Web page & 15 & $>50$ & 6 months \\
\hline
\end{tabular}

Abbreviation: NGO, non-governmental organization. 
had more to say than could be conveyed in one interview, a follow-up interview was conducted. In the end, seven informants were interviewed once and eight informants were interviewed twice. The young women received information about the research project in an introductory letter about the project through the different recruiting channels described above. They then contacted the researcher for more details and to find out how they might become part of the study. The interviews were then booked in consultation with the informants. To help the young women feel more in control of the interview situation they were asked to decide on a meeting place, where they could talk privately about their experiences and feel safe. ${ }^{35}$ Each informant was informed again about the project, this time verbally, and given a consent form that was signed.

The straightforward question, "Could you tell me about your experiences of selling sex online?" worked well for most of the informants and resulted in extensive dialog between the interviewer and the informant. Others needed a few more questions, such as "Could you tell me about the first time/a typical time/the last time you sold sex online?" The follow-up questions were intended to support each woman's narration about her experience of selling sex online.

\section{Analysis}

All interviews were taped and transcribed verbatim resulting in over 35 hours of audio and over 1,000 pages of transcribed material. When analyzing the material, thematic analysis was used, based on the principles of Braun and Clarke. ${ }^{36}$ According to these principles, the analysis involves examining a data set for repeated patterns of meaning. There are six steps in the thematic analysis: familiarization, generating initial codes, searching for themes, reviewing themes, defining and naming themes, and finally producing the report. In the current study, all six steps were done carefully. Each of the three authors read all the interviews several times independently, wrote down their initial impressions, and later the authors compared their ideas. Thereafter, the first author continued with the analysis, with support from the other two authors, who are both senior researchers in this field. The material was coded line by line and initial codes were written down and sorted into broader themes, which were reviewed and named. Three themes and eight sub-themes were identified. The themes were organized into three parts, each with its own storyline (Figure 1). A fourth theme concerned the establishment of a connection between buyer and seller. It was excluded from this paper, but is the focus of another article. ${ }^{22}$

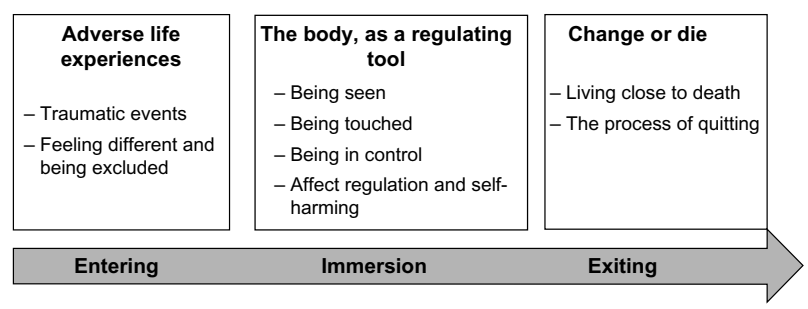

Figure I Themes and sub-themes related to the process of selling sex.

\section{Ethics}

Ethical considerations were observed before, during, and after the project. The interviewer has experience working in social services with vulnerable children, situations in which ethical considerations are very important, and has been part of similar research projects that involved interviewing children who were victims of sexual exploitation. In addition, both of the senior researchers in this project have worked both clinically and in their previous research with children and women who were victims of sexual and physical abuse. To make the interview situation as comfortable as possible for the informants, they were encouraged to decide where the meeting would take place. If the informant became upset or sad during the interview, the interviewer stopped and asked if she wanted to continue. So that the interviewer could consider the informants' body language, only face-to-face interviews in person were included. All informants signed a consent form before the interview and received written and verbal information after the interview about where to turn for therapeutic support, if needed. Six of the young women under the age of 18 gave consent for the interviewer to contact their parents and social services. The informants received two cinema tickets as remuneration for taking part in the study. In this paper all names, places, and details that could reveal the identity of the informants have been removed or anonymized.

Ethical approval was obtained from The Regional Ethical Review Board in Linköping, Sweden, 2010/158.

\section{Results}

Talking about their experiences of selling sex was challenging for the young women. Some told detailed stories from their lives while others found it difficult to put their experiences into words. Even if they struggled in the interviews to find a common term to describe their experiences of selling sex online, all the informants had contacted men or women online for sexual encounters offline and received various types of compensation. The types of compensation included money, drugs, telephone cards, and more. The narratives revealed 
similar experiences among the different women. Their stories revealed a downward spiral that some had been able to reverse and others had not. Some of the young women were still in the sex trade, struggling to find a different kind of life, while others had not sold sex for many years.

\section{Entering - adverse life experiences} Traumatic events

Although the interviewer did not ask the question "How did it all begin?", all of the informants began their interview by describing the different experiences that played a part in their entering into the sex trade. They talked about painful and unexpected loss, such as the accidental death of someone they had been close to. Sexual abuse was another experience they presented as being relevant to their entry into the online sex trade. Various forms of abuse were mentioned, ranging from being abused by a relative for as long as they could remember to being raped at a party by classmates.

Below is an excerpt from the interview with Nikki describing some of the life experiences that played a part in her future entry into the sex trade.

Well, there are really many things that played a part. It started maybe when I lost my younger sister in an accident. It was a catastrophe for my family. Well, many things have happened that I have blamed myself for [...] pretty much [...] And then there was the rape. I had been drinking and [...] later three boys raped me. I was in love with one of them, so that was the hard part. I didn't know how to react, since I had feelings for one of the boys. [Nikki]

The informants talked about how they were victims of different types of traumatic experiences that were out of their control. In addition to feeling victimized, some expressed feelings of guilt for what happened. For example, one woman described feeling responsible for her sibling's death since she was there at the time of the accident. Also, those who were victims of sexual abuse often said that they felt they had themselves to blame. Claudia described being sexually abused by her father: "The worst thing he [Dad] did to me was to make me feel guilty".

In a way, the young women viewed themselves as double victims: first as victims of an uncontrollable situation - the traumatic experience - and secondly as victims of feelings of guilt and responsibility.

The informants presented their traumatic experiences as life changing events.

I am an ordinary girl, or I was until all this happened.

I was playing a lot of soccer and I have always been good in school. But you see [...] after losing a sister, being raped and all that $[\ldots]$ life can never be the same again. It's like part of you dies and you can't repair it. Even if you talk about it or even if they were sentenced, it can never heal you. That must be normal, like it is for everyone being raped? You need to take care of this situation yourself. But my rape was also extremely cruel. I almost got killed. [Nikki]

\section{Feeling different and being excluded}

The informants' stories included descriptions of feeling different from other people. Some described having had these feelings for as long as they could remember while others traced their feelings back to traumatic experiences in their lives.

I'm not like everyone else. You know, I have been abused for a long time and so [...] only very weird people want to be with me, mostly to have sex. I would like to be a normal student in school, like most are [...] but that is impossible since I don't know how to be normal. [Mandy]

Feeling different affected their relationships with both family and friends. There were many stories of being bullied in school and not having close friends. Even if the young women could describe a social network including many people, these tended to be acquaintances, with very few close friends or family. For example, Diana struggled with poor psychological health and feelings of not belonging. She described being excluded from peer groups and being bullied in school.

If anyone had known when I was in school that I had psychological problems I might have been more understood.

But since I was strange I got bullied. I got to hear that it was my own fault that I was bullied, and that I was a whore, since I looked the way I did. [Diana]

And what did you look like? [Interviewer]

I had pink hair, rivets and bands and I was all dressed in black. I had a tough exterior so no one could see in. I felt very observed. And if you're used to people looking at you rather than seeing you for who you are, it doesn't feel that creepy. [Diana]

Along with exclusion from close relationships with friends, there were many stories of problematic relationships with parents. Some described having parents with an addiction or living in socially disadvantaged families. But first and foremost, the informants described living in families where they either did not talk to each other or argued a lot. In some cases the arguments escalated to physical violence. 
The informants said that their relationships with their families were similar to their relationships with friends, in that they felt they were outsiders and more or less excluded.

One response to their loneliness was to find people to talk to on the Internet. The young women described that they did not feel excluded in the same way online as they did offline since there was always someone to interact with. They described being on ordinary youth sites as well as on sites focusing on self-harming behavior and sex. Some contacts involved sending pictures and videos, which resulted in a lot of approaches, often of a sexual nature. Some of the contacts online led to meetings in person, meetings that turned out to be occasions for selling sex.

\section{Immersion - the body as a regulating tool}

The traumatic experiences suffered by the young women in this study, combined with their feelings of being different and excluded, were offered as an explanation as to why they entered the sex trade. Another part of the interview focused on motivations for selling sex and what functions or needs this behavior filled.

\section{Being seen}

Selling sex was described as a way to feel more important and as a solution to loneliness. The informants said that they sold sex to fill their need to be seen, appreciated, and affirmed. For example, the buyers sometimes told them that they were beautiful and important, and for some just being chosen among all the other sex sellers online was a kind of validation. The informants expressed that they wanted to perform well, to stand out among other sex sellers. Some also said that they hoped that the buyer would be a potential boyfriend. Holly talked about how she used her body, hoping to find a partner who could offer her a new kind of life.

\footnotetext{
I hoped they would take me away, save me from the situation I was in [...] I don't know [...] the reason [for selling sex] was mostly to get confirmation. They [the buyers] might say something about you, but not every time. I would be disappointed when they didn't say anything [...] I wanted to hear that I was good. If I didn't get to hear that, I might just start texting someone else at the same time $[. .$.$] because$ I just had to hear something nice [...] someone who said I was good at something. [Holly]
}

\section{Being touched}

To be touched and to have another person's full physical attention was presented by some of the young women as a need. However, all were clear that this need was not fully met by selling sex. Instead, selling sex was described more as a substitute for being close to another human being as a partner. Some of the informants clearly recognized that the sex trade was abusive, and separated their own sexuality from the act of selling sex. Others had difficulty distinguishing their own sexuality from abuse. Ella, said that what she hated the most about her body was that she could feel sexual arousal while selling sex. Her narratives included many stories of how her body let her down, leading to severe self-harming of her genitals and selling sex.

I feel so ashamed, so extremely ashamed [...] the absolutely worst thing was that my body let me down [...] my soul hated it but my body [...] sometimes I came [...] so fucking disgusting. Another thing that showed that it was my fault. If my body liked it then I really must have liked it [...] and I hate my body and I hate myself for it. That is why I harm myself. [Ella]

\section{Being in control}

Many of the informants described the sex selling as a way to gain a sense of control in their otherwise out of control lives. For example, some said that they loved the feeling of deciding whom to meet out of all their online contacts. Furthermore, knowing that they could easily destroy the buyer's life by revealing the situation to his boss or family also gave them a sense of control. On the other hand, they reflected on the possible consequences of revealing the information.

Last week when I was buying bread one of them [buyer] was there at ICA [Swedish grocery store]. He just quietly nodded and held his wife's hand. He had two kids also. I thought, ok, now I can turn around and say "hey, thanks for the pictures of your willie. When are we meeting next time?", but of course I didn't since I would have made a fool out of myself and him. But I think his wife would have started to ask him who I was. [Erica]

Some of the informants also expressed that they felt in control during certain aspects of the actual meetings with the buyers, while at other times they felt out of control. Several of those who had experienced sexual abuse related how they entered into the sexual encounters in order to gain a sense of control, something they lacked in earlier abusive situations. These young women described that they felt in control when deciding the amount of money to charge, even if they knew they would not always get it. Some talked about how they felt in control when setting up the meeting, but when it actually took place, they felt out of control again. 
I would say that it [selling sex] has to do with my abuse. When he abused me [...] or when I waited for him because I never knew when it would happen. Every time he went up the stairs I thought, ok, now it's time. I never knew, except for when he was drunk, because then I knew it would happen, just not the exact minute. But now, I know that on Tuesday at such and such a time I will meet a buyer and we have agreed on doing this and that, but I know things will be different when we meet [...] but at least we have a deal that I've been a part of. [Mandy]

\section{Affect regulation and self-harming}

All the informants in the study reported a poor sense of wellbeing and many expressed having either periodic or constant anxiety. They also said that their anxiety eased when they engaged in selling sex. Some described that the physical and psychological pain they felt during the sexual encounters made them feel alive and present, while others said that they felt as though they disappeared and went into a state of not being truly present.

When I feel bad I contact someone who wants to meet me. I feel so bad then that I'll do just about anything to relieve the pressure. Before the meetings the anxiety is so strong that I barely remember how I got there [...] then I shut down. Let someone else take me over and decide. I've become good at having sex with men, but that's not really what I want. Afterwards I feel like crap. Feel disgusting and empty. Often I am in a lot of pain. Usually I bite a shirt so as not to scream straight out [...] [Natalie]

It was not just bad feelings or anxiety that triggered them to sell sex. When they were very happy or excited and had a lot of positive feelings these were also regulated through sex selling.

Last year, at my birthday my parents told me I would get a nice present. I felt so excited and thought it would be a trip to a warm country. I don't like wearing bikini, so it was double feelings. In the evening we went to my grandmothers place and the present was a dog, my Bobo. He was so soft and cute. When we got home I was so happy and excited that I emailed with one of the men. [Selma]

Some of the young women described selling sex as a self-harming behavior, something they equated with cutting, burning the skin, etc. When Tracy was 13, her self-harming behavior (cutting) was so severe she had to move out of her family's home into a treatment clinic. At the clinic she was praised for stopping cutting herself. Since cutting was fairly visible, she exchanged that behavior for another less visible behavior - selling sex.

[...] and I was the good one who didn't self- harm anymore.

Everyone was so pleased, but I felt just as bad, I just found other ways $[\ldots]$ that weren't that visible [selling sex] [...] things that almost killed me for real. [Tracy]

Bonnie reported having cut herself more or less on a daily basis since she was 12 years old. She also used many other methods of self-harm and periodically had severe anorexia nervosa. She described feeling as if her life and body were destroyed which was why she felt she could hurt her body in different ways.

My body has no value for me, therefore I also can hurt it, starve it, cut it or have sex [...] it's so destroyed anyway. [Bonnie]

To harm oneself through selling sex was also explained as a response to feelings of being worthless and words such as hate, disgust, and being a bad person were used.

I don't like myself. It feels [...] as if my body has been a tool, you know [...] it hasn't belonged to the rest of me [...] it has been a way to hurt myself. But I have never liked big gatherings. I don't feel comfortable there. I don't think I'm the person others describe me as. I see myself as a worse person. I am not good at anything [...] well, except for sex, but that is hard with my boyfriend. [Claudia]

\section{Exiting - change or die}

The last part of the interview concerned the future and how the young women saw their situation in a long-term perspective. All of the informants realized that they themselves were the only ones who could change their situation, but this would be a struggle.

\section{Living close to death}

Most of the informants' lives were highly precarious, and the threat of death was close. Many feared for their lives in that they feared both that they might commit suicide and that they might get killed during a sex-selling meeting. Holly had sold sex on a daily basis since she was 14 to men she met via the Internet, but also to a teacher at her school, friends' fathers, and her own therapist. Just 2 weeks before the interview, she had told one of her customers that they had to stop seeing each other.

I just don't think I can do this anymore. It has to end, or mom and dad will have to bury me, and I don't want that [...] I don't want to die. And I can feel it right now, that I can't take it anymore. [Holly] 


\section{The process of quitting}

All of the informants knew from the first time they sold sex that they had to quit, but in reality, quitting was a much longer process. They related both negative and positive experiences that had played a part in their decision to stop selling sex. Some gave examples of meeting a buyer who was so violent that they feared for their lives, or making the final decision to quit after surviving a suicide attempt. Positive experiences also played a part. Most of these involved close friends or in some cases professional support personnel. This allowed them to realize that they could talk to and trust another person.

I got into the room and he [the buyer] was there with several others. I didn't care that much but I thought I was going to die, really! Afterwards I needed to go and see a doctor [...] I was so ashamed and decided that I need to stop this. [Linda]

I met Andy, and he knew what I was doing and said that I couldn't do it anymore. His mom is a psychologist and I talked to her. That was good. They saved my life I would say. [Selma]

Some of the young women went to the police after having been threatened by buyers and fearing for their lives. Meetings with the police were also, for some, identified as a turning point - an event that forced them to consider an alternative to a life of selling sex.

This was inevitable. But I can tell you that what really helped was my blog, where I was open about all of my self-destructiveness. I just couldn't let the followers down by cutting myself or selling sex. I needed to be trustworthy and not fool them. That's what really changed my life.

[Diana]

The challenging process of quitting involved both progress and regression. During periods of poor psychological health informants' self-destructiveness increased, resulting in visits to online sex sites and selling sex. They referred to themselves as being caught in a behavior that was impossible or very difficult to break out of. Typically, throughout the interview the young women expressed the clear opinion that selling sex is not for children and that in the long run they would like to use their own experience to help children who are selling sex.

I know that children shouldn't sell sex. I know that, but I just can't do anything else. I have tried, but this is my faith. I will try again though, and next time we meet, I will be married with two kids and living a happy life [laughter].
I would never let my kids sell sex, no children should be in this business. When I'm out of this, I'm going to spend the rest of my life working preventatively. [Johanna]

\section{Discussion}

The narratives about selling sex as children were stories with a clear beginning and an ongoing struggle towards disengagement. For all the young women, the beginning was associated with some kind of life-altering experience and with feelings of being different and excluded.

The informants described both potentially traumatic events and severe traumatic experiences that had played a part in the process of starting to sell sex. These descriptions are in line with previous research that has shown a clear association between traumatic experiences and sex selling among adolescents. ${ }^{8,15,16,20}$ The traumatic experiences were identified as life changing and could be seen as turning points in life. ${ }^{37}$ Turning points with both positive and negative characteristics have been described as keys to the decision to exit the sex trade among adults, ${ }^{29}$ but in this study they also seemed to play a part in the decision to enter the sex trade for several of the informants.

The young women referred to themselves as victims of life changing events, situations that had been difficult or impossible to control. However, when they talked about their experiences selling sex, they did not describe themselves as victims even if they had been children at the time. There were many stories of sex selling encounters that were out of control, but the informants held themselves accountable for the decision to sell sex. This could be understood since they themselves contacted the buyers in the first place and had some kind of agreement before the meetings. Parallels may also be drawn to theories which suggest that victims of sexual abuse may attempt to recreate earlier abusive situations in a way that makes them feel more in control. ${ }^{38}$ This could be one explanation for the clear association between selling sex and sexual abuse among adolescents in this and other studies. ${ }^{15}$ The young women also talked about feeling different and excluded, some for as long as they could remember. It is plausible to think that their traumatic experiences may have contributed to these feelings. Previous research has also shown that both sexual abuse and selling sex can lead to feelings of stigmatization. ${ }^{39}$ From this perspective, some of the informants can be seen to have gone from one stigmatizing experience (sexual abuse) to another more "self-controlled" form of stigmatization (selling sex). ${ }^{40}$

From another perspective, the traumatic experiences can be interpreted within the context of loss. The informants 
described being victims of different losses - of a sibling, their body, their childhood, or their ability to have close relationships without sex. In research on loss, Gringeri and Vogel-Ferguson identified six kinds of losses resulting from maltreatment (including sexual abuse) in childhood: relational, personal, material, learning, institutional failure, and loss of trust in social institutions.$^{41}$ Relational loss means that the maltreatment results in a loss of trust in others, which makes relationships difficult and likely to be avoided. All of the young women interviewed reported feeling excluded and different, which could be seen as a "relational loss" resulting from their traumatic experiences.

Experiences of sexual abuse can lead to self-loathing or feelings that the body has been damaged. ${ }^{42,43}$ In the current study, many of the narratives focused on the body. Selling sex was identified as a way to survive, as self-medication. The informants described using their body as a tool for regulating feelings, both positive (eg, happy and exciting) and negative (eg, anxiety and loneliness). Parallels might be drawn to self-harming behaviors that also can serve to affect regulation. ${ }^{44}{ }^{47}$ Studies have shown an association between young people's sex selling and self-harming behaviors. ${ }^{15}$ The interviews in our study indicated that not only are sex selling and self-harming behaviors associated with each other, but according to the informants, sex selling can be considered a form of self-harm. Further studies are needed to examine whether or not sex selling can be considered to be a form of a non-suicidal self-injury behavior (direct form with tissue damages) or as a close but indirect form. A study that simultaneously investigates what functions these two behaviors serve would be of special interest.

Some of the informants had stopped selling sex many years ago and some were still struggling to quit. All of these young women were certain that they needed to stop selling sex. Quitting, however, was a process, which included turning points similar to those involved in entering the sex trade. The exit process began on the first sex-selling occasion, and was described as challenging. Researchers have investigated the exit process, particularly for women in street-based prostitution. ${ }^{30}$ Månsson and Hedin found that the pre-exit process included turning points such as eyeopening events, traumatic events, and positive life events. ${ }^{29}$ The authors also outlined other strategies that were more gradual and undramatic for example, phasing out sex selling by gradually limiting the range of sexual services provided, reducing their presence and exposure to sex work, or seeing only regular customers. There are similarities between the results of the Månsson and Hedin study ${ }^{29}$ and the narratives of the young women in our study, particularly regarding the challenging process of exiting. Further studies are needed, however, to identify similarities and differences in the exit process for children and adults in both online and offline environments.

The Internet is an important factor in any discussion of the online sex trade since it facilitates the connections between buyers and sellers. ${ }^{15,22,31}$ The narratives of the informants in this study also pointed to the importance of the Internet community. The young women expressed feeling excluded in real life, for example, at school, but when they were on the Internet they felt included in an alternative community. In the online community they were considered normal and were accepted, at least in groups that focused on self-harming behavior and sex.

The importance of the Internet community was also clear in the informants' descriptions of their struggles to extricate themselves from the sex trade. In their stories, the young women endeavored to portray themselves as reliable and trustworthy persons. According to the theories of Goffman, we present ourselves as respectable individuals in our interactions with others. ${ }^{48}$ It is likely that we present ourselves in this way whether we are in an online or an offline environment. The informants in our study reported that they felt their blog or twitter followers were friends and that they had a relationship based on mutual trust. For young people with problematic relationships within their social networks in the real world, online contacts can be very important and may help them make contacts outside the Internet.

This study has several limitations that need to be addressed. The female informants all lived in Sweden in relatively safe social circumstances, and their primary motivation for selling sex was not money, drugs, or alcohol. All of them also had a home and did not sell sex for a place to stay. Therefore our conclusions should be read with caution, and may not be relevant for all young women in the online sex trade who live in other parts of the world and for those having other motivations for selling sex.

Since there are only a few studies involving children selling sex online, our results must be compared with caution to other similar qualitative studies. The results are based on interviews with 15 female informants, which resulted in more than 1,000 pages of text to analyze. Although it was challenging for us to find informants, the optimal number of informants for a qualitative study depends on the subject of the study. ${ }^{49,50}$ Polit and Beck describe that qualitative researchers often use the principle of saturation to decide when no new informants need to be included in a study. ${ }^{50}$ 
Saturation occurs when themes and categories in the data become repetitive and redundant, and that further data collection will not add anything new. In the current study the material was considered to have reached data saturation after 15 interviews.

The stories told by the young women included events that had happened in the past. In all retrospective studies there is the risk of memory bias, and it is possible that the informants who had exited the sex trade many years ago looked at their experiences differently from those who were still selling sex.

The TFI model worked well for this study and gave the interviews a solid framework that was an advantage for the informants. However, their contributions were not equally distributed. Some of the women, among them, those who had been in therapy, talked quite articulately about their experiences. Others, especially the youngest with no experience of therapy, were coaxed with difficulty to describe their experiences in response to open questions ("Can you tell me ...."). They gave more brief and report-like answers to direct questions. Therefore, it is possible that the young women with the richer narratives received more attention in the analysis than did the others.

In conclusion, the informants all had stable social lives in the sense that they had roofs over their heads, food to eat, and no substance-abuse issues. None had a third party who arranged the sexual contacts and none were currently trafficked. The informants in our study had other reasons for selling sex. They described how their experiences of traumatic events and of feeling different and excluded had led them into the sex trade. They used selling sex as a way of being seen, a way to handle experiences of sexual abuse, and as a tool for regulating feelings. To be able to support these young women, it is imperative to offer appropriate support and treatment programs especially designed for this group of young people.

The informants reported that they felt that they were the only ones who could make a change in their lives, which is understandable considering how their experiences had led to a lack of trust in their social networks. A relationship with a school nurse or therapist, for example, might offer guidance on how to build relationships with other people and help with processing their traumatic experiences and ending self-harming behavior, but might involve a lengthy process of working towards establishing trust. For parents and professionals such as teachers, social workers, and therapists dealing with young people selling sex, it is important to understand that symptomatic behavior needs to be addressed and to hear the subtle signals asking for help. The young women showed through their stories that they are strong, energetic, and possess a significant degree of agency important strengths, upon which helping professionals can build in their efforts to support these women. The study also showed that there are opportunities to intervene at every point in the process, since the informants reported wanting to quit from the very first time they sold sex. Further studies are needed, especially dealing with the exit process for children who sell sex online. A deeper understanding of this process may be valuable for professionals who work with children involved in the online sex trade.

\section{Acknowledgments}

The study was made possible by grants from the Swedish National Board for Health and Welfare and the Crime Victim Fund in Sweden.

\section{Disclosure}

The authors report no conflict of interest in this work.

\section{References}

1. Pedersen W, Hegna K. Children and adolescents who sell sex: A community study. Soc Sci Med. 2003;56(1):135-147.

2. Svedin CG, Priebe G. Selling Sex in a Population-Based Study of High School Seniors in Sweden: Demographic and Psychosocial Correlates. Arch Sex Behav. 2007;36(1):21-32.

3. Lavoie F, Thibodeau C, Gagne MH, Hébert M. Buying and selling sex in Québec adolescents: a study of risk and protective factors. Arch Sex Behav. 2010;39(5):1147-1160.

4. United Nations [homepage on the Internet]. 54/263. Optional protocols to the Convention on the Rights of the Child on the involvement of children in armed conflict and on the sale of children, child prostitution and child pornography; 2000. Available from: http:/www.un-documents. net/a54r263.htm. Accessed September 11, 2014.

5. Coy M. Invaded spaces and feeling dirty: Women's narratives on violation in prostitution and sexual violence. In: Horvath, M editor. Rape: Challenging Contemporary Thinking. Devon: Willian (Willian) Publishing; 2009:184-206.

6. Coy M, editors. Prostitution, Harm and Gender Inequality. Theory, Research and Policy. Farnham: Ashgate; 2012.

7. Government Offices of Sweden [homepage on the Internet]. The Swedish Penal Code, Chapter 6, 1962:700; 2014. Ministry of Justice. Available from: http://www.government.se/sb/d/574/a/47455. Accessed August 6, 2013.

8. Edwards JM, Iritani BJ, Hallfors DD. Prevalence and correlates of exchanging sex for drugs or money among adolescents in the United States. Sex Transm Infect. 2006;82(5):354-358.

9. Fredlund C, Svensson F, Svedin CG, Priebe G, Wadsby M. Adolescents' lifetime experiences of selling sex. Development over five years. JChild Sex Abus. 2013;22(3):312-325.

10. Johnson RJ, Rew L, Sternglanz RW. The relationship between childhood sexual abuse and sexual health practices of homeless adolescents. Adolescence. 2006;41(162):221-234.

11. Kidd SA, Kral MJ. Suicide and prostitution among street youth: A qualitative analysis. Adolescence. 2002;37(146):410-420.

12. Roe-Sepowitz DE. Juvenile entry into prostitution: The role of emotional abuse. Violence Against Women. 2012;18(5):562-579. 
13. Bagley C, Young L. Juvenile prostitution and child sexual abuse: A controlled study. Canadian Journal of Community Mental Health. 1987;6(1):5-26.

14. Wilson HW, Widom CS. The role of youth problem behaviors in the path from child abuse and neglect to prostitution: A prospective examination. J Res Adolesc. 2010;20(1):210-236.

15. Svensson F, Fredlund C, Svedin CG, Priebe G, Wadsby M. Adolescents selling sex: Exposure to abuse, mental health, self- harm behaviour and the need for help and support-a study of a Swedish national sample. Nord J Psychiatry. 2013;67(2):81-88.

16. Kaestle CE. Selling and Buying Sex: A Longitudinal Study of Risk and Protective Factors in Adolescence. Prev Sci. 2012;13(3):314-322.

17. Pearche JJ, Galvin C, Williams M. It's Someone Taking a Part of You. A Study of Young Women and Sexual Exploitation. London: National Children's Bureau Enterprises Ltd.; 2003.

18. Roy E, Haley N, Leclerc P, et al. Prevalence of HIV infection and risk behaviours among Montreal street youth. Int J STD AIDS. 2000;11(4): 241-247.

19. Tyler K, Whitbeck LB, Hoyt DR, Cauce AM. The effects of a high-risk environment on the sexual victimization of homeless and runaway youth. Violence Vict. 2001;16(4):441-455.

20. Nadon SM, Koverola C, Schludermann EH. Antecedents to prostitution. Childhood victimization. Journal of Interpersonal Violence. 1998 13(2):206-221.

21. Martin L, Hearst MO, Widome R. Meaningful differences: Comparison of adult women who first traded sex as a juvenile versus an adult. Violence Against Women. 2010;16(11):1252-1269.

22. Jonsson LS, Svedin CG, Hydén M. "Without the Internet, I never would have sold sex": Young women selling sex online. Cyberpsychology: Journal of Psychosocial Research on Cyberspace. 2014;8(1): article 4.

23. Jonsson L, Svedin CG. “Online är jag någon annan ....” Unga kvinnor med erfarenhet av att sälja sexuella tjänster online. Delrapport 8 i Prostitution i Sverige- Kartläggning och utvärdering av prostitutionsgruppernas insatser samt erfarenheter och attityder i befolkningen ["Online I am someone else ..."Young women with experiences of selling sex online. Report 8 from Prostitution in Sweden, Mapping and evaluation of the Swedish prostitution units' interventions for people who have sold or bought sex as well as mapping of experiences and attitudes in the general population]. Lund och Linköping: Lunds-och Linköpings Universitet Electronic Press; 2012;38.

24. Estes RJ, Weiner NA. The Commercial Sexual Exploitation of Children in the US, Canada and Mexico. University of Pennsylvania School of Social Work; 2001.

25. Finkelhor D, Ormrod R. Prostitution of juveniles: Patterns from NIBRS. Juvenile Justice Bulletin. NCJ203946 (1-12). Washington, DC: US Government Printing Office; 2004.

26. Silbert MH, Pines AM. Entrance into prostitution. Youth and Society. 1982;13(4):471-500.

27. United Nations [homepage on the Internet]. United Nations Convention Against Transnational Organized Crime and the Protocols Thereto. The Protocol to Prevent, Suppress and Punish Trafficking in Persons, Especially Women and Children. United Nations; 2004. Available from: http://www.unodc.org/documents/treaties/UNTOC/Publications/ TOC\%20Convention/TOCebook-e.pdf. Accessed October 13, 2013.

28. van de Walle R, Picavet C, van Berlo W, Verhoeff A. Young Dutch People's Experiences of Trading Sex: A Qualitative Study. J Sex Res. 2012;49(6):547-557.

Adolescent Health, Medicine and Therapeutics

\section{Publish your work in this journal}

Adolescent Health, Medicine and Therapeutics is an international, peer-reviewed, open access journal focusing on health, pathology, and treatment issues specific to the adolescent age group. All aspects of health maintenance, preventative measures and disease treatmen interventions are addressed within the journal and practitioners from
29. Månsson SA, Hedin, UC. Breaking the Matthew effect - on women leaving prostitution. International Journal of Social Welfare. 1999; 8(1):67-77.

30. Baker LM, Dalla RL, Williamson C. Exiting Prostitution. An Integrated Model. Violence Against Women. 2010;16(5):579-600.

31. Cunningham S, Kendall, TD. Prostitution 2.0: The changing face of sex work. Journal of Urban Economics. 2011;69(3):273-287.

32. Cooper A. Sexuality and the Internet. Surfing into the New Millennium. CyberPsychology and Behavior. 1998;1(2):187-193.

33. Pulerwitz J, Gortmaker SL, DeJong W. Measuring sexual relationship power in HIV/STD research. Sex Roles. 2000;42(7-8):637-660.

34. United Nations [homepage on the Internet]. Convention on the rights of the child. United Nations Human Rights; 1989. Available from: http://www.ohchr.org/en/professionalinterest/pages/crc.aspx. Accessed October 12, 2013.

35. Hydén M. The teller-focused interview: Interviewing as a relational practice. Qualitative Social Work. 2014:13(6):795-812.

36. Braun V, Clarke V. Using thematic analysis in psychology. Qualitative Research in Psychology. 2006;3(2):77-101.

37. Wheaton B, Gotlib IH. Trajectories and turning points over the life course: Concepts of themes. In: Gotlib IH, Wheaton B, editors. Stress and Adversity Over Life Course: Trajectories and Turning Points. Cambrigde, UK: Cambridge University Press; 1997;1-25.

38. Gleiser KA. Psychoanalytic perspectives on Traumatic Repetition. Journal of Trauma and Dissociation. 2003;4(2):27-47.

39. Finkelhor D, Browne A. The traumatic impact of child sexual abuse: A conceptualization. Am J Orthopsychiatry. 1985;55(4):530-541.

40. Goffman E. Stigma- den avvikandes roll och identitet. [Stigma]. 4th ed. Lund: Studentlitteratur; 2014.

41. Gringeri C, Vogel-Ferguson MB. Childhood abuse and loss in lives of low-income women. Qualitative Social Work. 2012;12(5):654-670.

42. Rathsman K. Incest: Att bo i en stulen kropp. [Incest: to live in a stolen body.] Lund: Studentlitteratur; 2001.

43. Stroebel SS, O'Keefe SL, Beard KW, Kuo SY, Swindell S, Stroupe W. Brother-Sister Incest: Data from Anonymous Computer-Assisted Self Interviews. J Child Sex Abus. 2013;22(3):255-276.

44. Klonsky ED. The functions of deliberate self-injury: A review of the evidence. Clin Psychol Rev. 2007;27(2):226-239.

45. Lloyd-Richardson EE, Perrine N, Dierker L, Kelley ML. Characteristics and functions of non-suicidal self-injury in a community sample of adolescents. Psychol Med. 2007;37(8):1183-1192.

46. Nock MK, Prinstein MJ. Contextual features and behavioral functions of self-mutilation among adolescents. J Abnorm Psychol. 2005;114(1): 140-146.

47. Dahlström Ö, Zetterqvist M, Lundh LG, Svedin CG. Functions of Non-Suicidal Self-Injury in a Community Sample of Adolescents Generation and Validation of Underlying Factors. Psychological Assessment. In press 2015.

48. Goffman E. Jaget och maskerna. En studie $i$ vardagslivets dramatik. [The presentation of self in everyday life]. Stockholm: Norstedts; 2009.

49. Patton MQ. Qualitative Research and Evaluation Methods. 3rd ed. Thousand oaks: Sage Publications; 2002.

50. Polit DF, Beck, CT. Nursing Research. Generating and Assessing Evidence for Nursing Practice. 8th ed. Philadelphia: Lippincott Williams \& Wilkins; 2008.

all disciplines are invited to submit their work as well as healthcare researchers and patient support groups.. The manuscript management system is completely online and includes a very quick and fair peerreview system. Visit http://www.dovepress.com/testimonials.php to read real quotes from published authors. 